\title{
METAPHORICAL EXPRESSION USED IN POETRY IN ENGLISH TEXTBOOK ENTITLED "PATHWAY TO ENGLSIH"
}

\author{
Serefina Veronika Ketaren ${ }^{1}$, Emma Martina Br. Pakpahan² \\ 1,2 Universitas Prima Indonesia \\ ${ }^{1}$ serefinaketaren@gmail.com, ${ }^{2}$ emmathina@gmail.com
}

\begin{abstract}
The aims of this research are to find out the types and meaning of metaphor in poetry in English textbook entitled "Pathway to English". The main data of this research are 9 poetry in the English textbook entitled "The Seasons", "The Little Rose Tree", "Alpine Glow", "From Alcuin", "A Man Young and Old: Human Dignity", "Love and Friendship", "Mountain", "My Star", and "I Wandered Lonely as a Cloud". In this research the researcher applied descriptive qualitative method to analyze the data. The researcher used theory of Parera to classify the types of metaphor and also used the metaphor identification procedure proposed by Pragglejaz to identify the metaphors contained in the poetry. The result showed that there are 22 lines that used metaphor, which 16 lines are anthropomorphic metaphor, 3 lines are synesthetic metaphor, 2 lines are metaphor abstract to concrete and 1 line is animal metaphor. The meaning of all these poetry is about life. By using metaphor the poet can also express their feelings to the reader to understand the implicit message contained in the poetry through the depiction or comparison made by the poet.
\end{abstract}

Keywords: English Textbook, Metaphor, Poetry

\section{INTRODUCTION}

Linguistics is a scientific study that focuses on language that explores the sound system, meaning, and construction of expression rules. Linguistics has many branches, one of the branches of linguistics is semantics. According to KBBI semantics is the meaning, meaning of the speaker and writer, or the meaning given in the form of discussion.

In the process of delivering messages, there are two ways that can be done. First, the message can be conveyed directly through the use of ordinary language without causing confusion in the mind of the listener or reader because of the unclear meaning and message conveyed. Second, delivery is indirect or implied. The message is conveyed not in ordinary language so that this creates ambiguity in the minds of listeners or readers. In this case usually the writer or speaker uses figurative language. Figurative language is usually used to analyze the deeper meaning of words. There are various kinds of figurative language, such as metaphor, litotes, onomatopoeia, personification, alliteration, allusion, hyperbole, irony, synecdoche, simile and etc. Among of those kinds, there is a kind that is often used in daily communication and in literary work, namely is metaphor.

According to (Classe, 2000) metaphor is the transfer of the image, meaning, or quality of an expression to another expression. The transfer is done by referring to a concept to another concept to imply the similarity, analogy or relationship between the two concepts. Metaphors describe the same thing or have the same value as other things, but actually these things are different. Metaphors are found in literary work such as poetry, prose and songs. 
According to (Robert, 2006) literature is a composition that tells a story, dramatizes a situation, expresses emotions, experiences and suggests ideas. Every literary work is full of meaning as an expression of the author's feelings. Many literary works are created based on the personal life experience of the author or the surrounding community which is full of meaning. One of the literary works that is interesting to examine is poetry.

According to (Waluyo, 2002) poetry is a literary work with a language that is condensed, shortened, and rhymes with a unified sound and using figurative language. Poetry, in which the meaning of the text is constructed using figurative language is a part of literary work that is always used to teach students when introducing figurative language, especially metaphors.

Currently, in the Indonesian education curriculum (curriculum 2013) English lessons are divided into two kinds of teaching and learning programs. They are obligation English and specialization English. In the specialization English textbook of senior high school, especially in the eleventh grade, several topics about poetry are found. This topic is studied by students to determine students' abilities about art or literature in language teaching. The name of English textbook is "Pathway to English grade XI". The reason why researcher uses this textbook is because it is a series of English courses currently used for high school students. It w a s aimed to provide a framework for learning English regarding figurative language, especially in metaphorical expressions. So, students can understand the message the poet wants to convey to the readers or listeners from the poetry contained in the English textbook. Based on the background of study, the problem of study was stated as the following:

1. What metaphorical expressions are found in poetry in English textbook?

2. What meaning does the poet want to convey to the readers?

\section{Metaphor}

According to the (Peter, 2002), metaphor is the figurative language, which compares one thing to another directly. (Lakoff \& Johnson, 1980) define metaphor as a device of the poetic imagination and the rhetorical flourish-a matter of extraordinary rather than ordinary language. According to KBBI metaphor is the use of words nor a group of words not in their true meaning but as a painting which is based on equations or comparisons.

From some of the opinion above, the researcher concludes that metaphor is a figurative language that transfers of meaning to analogize a concept with another concept that has the same content or value.

\section{Types of Metaphors}

There are several theories put forward by experts about the types of metaphors. One of them is the Parera's theory. According to (Parera, 2004) metaphors can be divided into 4 groups, namely:

1. Anthropomorphic metaphor

Anthropomorphic metaphor is used to compare the similarity of experience with what is contained in the body of the metaphor user. Language's users compare the similarity of experience to what is in itself or their own bodies. In anthropomorphic metaphors there is a word relation supposed to be specifically used for a human feature or element, but associated with inanimate objects.

2. Animal Metaphor

Animal metaphors are metaphors that show the existence associations comparing the characteristics of the animal and human nature that appear. Actually what is being compared is not only the characteristics, but also the elements of the body animal. The 
embodiment of the animal metaphor in general can be done from animal to plant, animal to human, and from animal to inanimate objects.

3. Metaphors from abstract to concrete

A metaphor from abstract to concrete is a type of metaphor of diversion or transferring abstract expressions to concrete expressions.

4. Synesthetic metaphor

Synesthetic metaphor is a type of metaphor diversion of the senses, transfer from one sense to another. Basic creation this metaphor is a diversion of responses based on the experience of understanding one to another. Expressions can be created by diversion stimulus from one sense organ to another, for example from the senses listener to the sense of sight, from the sense of touch to the sense of hearing, and etc.

To conduct this research, the researcher takes some previous studies which have the same field such as (Ulfa, 2016) who analyzed the use of metaphor in Anne Bradstreet's poems. In analyzing the types and meaning of metaphor, she used (Parera, 2004) theory. In result, she found that there were four types of metaphor used in Bradstreet's poems namely anthropomorphic metaphor, animal metaphor, metaphor from abstract to concrete and synesthetic metaphor.

Another study was done by (Syarwani, 2017) who analyzed metaphor that was used in Emily Dickinson's poems. In his research, he investigated the types and the implicit meaning of metaphors. He used (Lakoff \& Johnson, 1980) theory to identify and analyzed the data. In the result of the study, he found that there were three types of metaphor used in Emily Dickinson's poems namely structural metaphor, ontological metaphor, and orientational metaphor. In addition, the implicit meaning of metaphor talks about life, love and sadness. In this study, the researcher did not include animal as a source of metaphor formation. In fact, the animal world can be said to be a source of a creative metaphor formation.

Based on the explanation of previous research, the researcher decides to use the theory from Parera because the theory from Lakoff and Johnson had been ancient. Thus, researcher needs to use newer theory. Another reason is because this theory is still new, so that in previous studies there were only few other researchers who used Parera's theory. So that new research is needed to add references and understanding of the use of this theory in classifying types of metaphors.

\section{Procedure for Identifying the Metaphors}

The metaphor identification procedure (MIP) is a method for identifying words that are used metaphorically in literary works. The procedures aim at determining the relationships of certain lexical units in literary works and recognizing their use in certain contexts as metaphorical possibilities. A group of scholars called (Pragglejaz, 2007) formulated the Metaphor Identification Procedure as follows:

1. Read discourse thoroughly to build a general understanding of its meaning.

2. Define lexical units in discourse:

a) For each lexical unit in the text, look at its meaning in context, that is, how that meaning works as an entity, relation, or attribute in the situation posed by the text (contextual meaning). Count what comes before and after the lexical unit.

b) For each lexical unit, determine whether the unit has a more basic contemporary meaning in another context. In honing this metaphor, the basic meanings tend to: (i) be more real (what is served is easier to imagine, see, hear, touch, smell, and feel); (ii) relating to physical acts; (iii) More precise (not obscure); and (iv) 
historically older. The basic meaning must be the meaning that arises most frequently from the lexical unit.

c) If the lexical unit has a more basic contemporary meaning in another context than the existing context, check whether the contextual meaning differs from the basic meaning but can be understood by means of a comparison with that basic meaning.

3. Mark the lexical unit as metaphorical.

Based on previous reserachers, (Pariasa, 2017) said that the method of metaphor identification procedure (MIP) should be applied because it provided an explicit, reliable, flexible instrument for identifying linguistic metaphors. So, the researcher hope that using metaphor identification procedure can help researcher in analyzing poetry and by using MIP the researcher has a theoretical basis to assist in identifying linguistic metaphors.

\section{METHOD}

In this research, the researcher applied descriptive qualitative method in order to analyze the metaphorical expression used in the poetry. The researcher analyzed poetry in English textbook entitled "Pathway to English grade XI". This method was carried out by using the theory of Parera about metaphors to find out what types of metaphors are in the poetry in English textbook.

Descriptive analysis is a form of research aimed at describing existing phenomena, both natural and man-made. These phenomena can be in the form of characteristics, changes, relations, similarities, and differences between one phenomenon and another. Descriptive research is not only limited to the problem of data collection and preparation, but also includes data analysis and data interpretation (Sukardi, 2006).

The Data are derived from the metaphorical expression that found in the poetry in English textbook entitled "Pathway to English". The data of this research has been presented in written form, in which it describes the results of the analysis related to the metaphorical expression used in the poetry. The researcher has observed the data from English textbook first. English textbook entitled "Pathway to English" is a series of English courses currently used for high school students in grade XI. This book is arranged for the learning process, and contains materials or subject matter to be taught.

To collect data, the researcher took the following steps. First, take poetry from an English textbook entitled "Pathway to English grade XI". Secind, read poetry from English textbooks. Third, find out the metaphorical expressions used in the poetry in relation to those formulated by (Pragglejaz, 2007). Fourth, write down the data. Fifth, organize the data into several parts based on the type of metaphor presented by (Parera, 2004). And the last, find out the meaning conveyed in each poem in the English textbook entitled "Pathway to English grade XI".

In this analysis the researcher used the following procedure:

1. Identification

After collecting the data, the researcher identified the data based on the types of metaphors according to Parera to make it easier to classifying data.

2. Classification

The researcher classified each use of Metaphorical Expressions according to Parera based on the types of metaphors. 
3. Data Analysis

After classifying the types of metaphorical expressions, the researcher analyzed the data of metaphorical expressions used in poetry in the English text book "Pathway to English". The data analysis steps are presented as follows:

a) Read and observed the metaphorical expressions used found in poetry.

b) The researcher listed the data found in poetry.

c) The researcher analyzed the meaning contained in the poetry.

\section{RESULTS AND DISCUSSION}

\section{Results}

\section{Types of Metaphors}

After analyzing the data, the researcher found the types of metaphor in poetry in English textbook. The total of the data were 9 poetry. The poetry took from English textbook entitled pathway to English that consist of the seasons, the little rose tree by Rachel Field, alpine glow by Emily Dickinson, from alcuin by Ralph Wando, a man young and old: human dignity by William Butler, love friendship by Emily Bronte, mountain by Ika, my star by Robert Browning, and I wandered lonely as a cloud by William Wordswoth. The researcher used the theory from (Parera, 2004). He also classified metaphor into 4 types, namely: anthropormorphic metaphor, animal metaphor, metaphor abstract to concrete and synesthetic metaphor. The researcher classified the metaphors of the poetry into table based on the verse.

The Results should include the rationale or design of the experiments as well as the results of the experiments. Results can be presented in figures, tables, and text. The Results should include the rationale or design of the experiments as well as the results of the experiments. Results can be presented in figures, tables, and text. The Results should include the rationale or design of the experiments as well as the results of the experiments. Results can be presented in figures, tables, and text.

Table 1. Number of Students Based Early Mathematical Ability

\begin{tabular}{llc}
\hline \multicolumn{1}{c}{ Title of Poem } & \multicolumn{1}{c}{ Line } & Type of Metaphor \\
\hline \multirow{3}{*}{ The Seasons } & Spring is a lovely lady & $\begin{array}{c}\text { Anthropomorphic } \\
\text { Metaphor }\end{array}$ \\
\cline { 2 - 3 } & Autumn's hair is golden & $\begin{array}{c}\text { Anthropomorphic } \\
\text { Metaphor }\end{array}$ \\
\cline { 2 - 3 } & She enjoys the fruit of the harvest & Anthropomorphic \\
& and mellow light over all & Metaphor \\
\cline { 2 - 3 } & Winter's sleeping giant & Anthropomorphic \\
& Metaphor \\
\hline
\end{tabular}




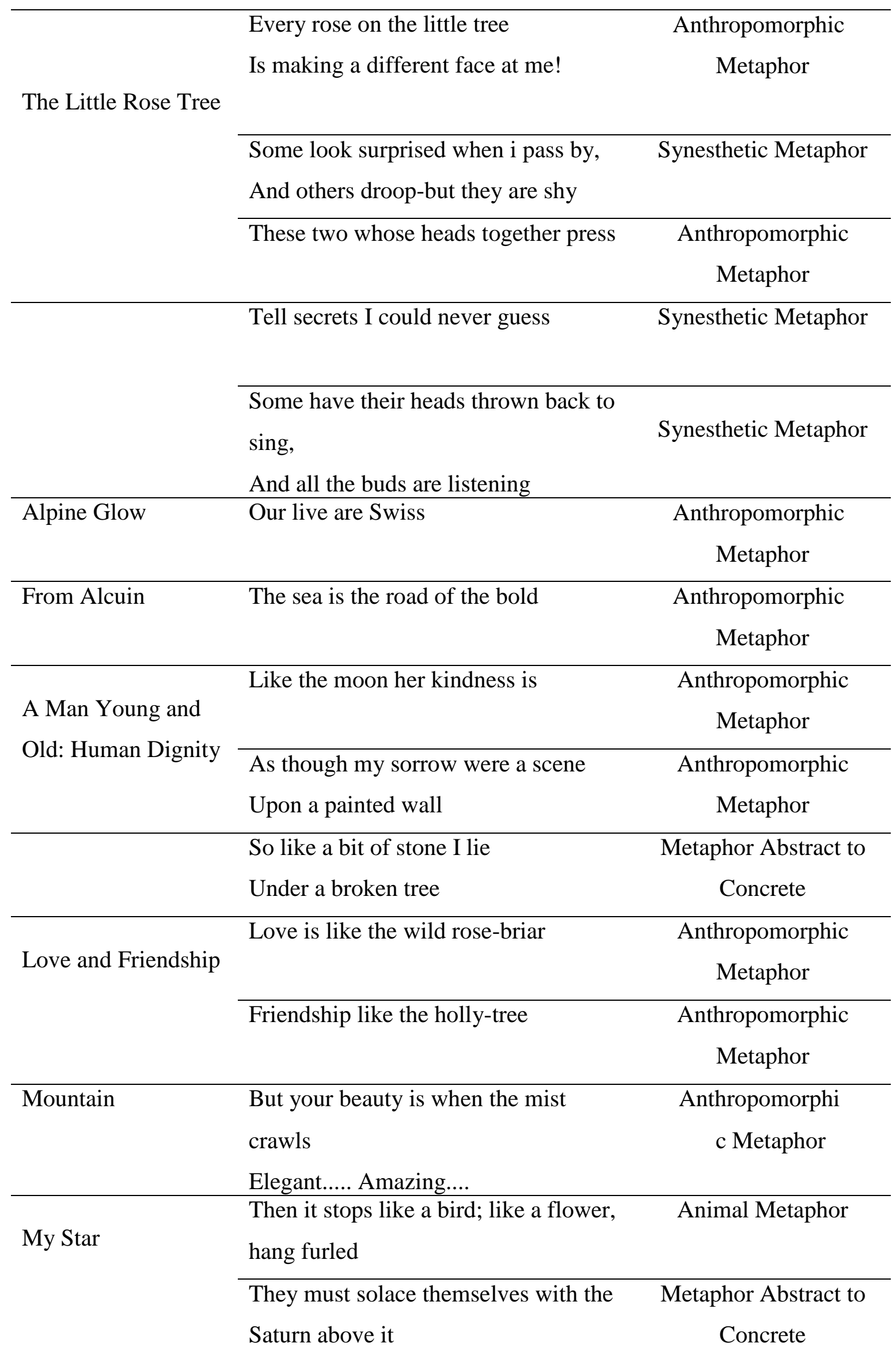




\begin{tabular}{llc}
\hline & $\begin{array}{l}\text { I wandered lonely as a Cloud } \\
\text { That floats on high o'er vales and hills }\end{array}$ & $\begin{array}{c}\text { Anthropomorphic } \\
\text { Metaphor }\end{array}$ \\
\cline { 2 - 3 } I Wandered Lonely & $\begin{array}{l}\text { Tossing their heads in sprightly dance } \\
\text { as a Cloud }\end{array}$ & $\begin{array}{c}\text { Anthropomorphic } \\
\text { Metaphor }\end{array}$ \\
\cline { 2 - 3 } & $\begin{array}{l}\text { The wave beside them danced, but } \\
\text { they outdid the sparkling waves in }\end{array}$ & Anthropomorphic \\
& Glee & Metaphor \\
\hline
\end{tabular}

\section{Meaning of Metaphor}

After analyzing the data, the researcher found several meanings in each poetry that the poet wanted to convey to the readers through the use of figurative language such as metaphor.

The Seasons

\section{Spring is a lovely lady}

Spring is synonymous with the season where the plants bloom again so that spring is also called the flower season. In this verse, spring is likened to lady, who has a beauty like flowers.

\section{Autumn's hair is golden}

In autumn the leaves change color on the trees to red, orange red and golden yellow so that the beauty of nature becomes beautiful to look at. while the word hair is a crown for women. So that in this stanza, the beautiful autumn is likened to the hair which is the crown of women.

She enjoys the fruit of the harvest and mellow light over all

The word mellow light is not the light that can be felt or the light on living things, but the word mellow light as a description of the good weather so it is suitable to be used as the right time to relax.

\section{Winter's a sleeping giant}

In winter, people usually reduce activities or activities outside the home, while the sleeping giant describes a human being hibernating in winter.

The Little Rose Tree

by Rachel Field

Every rose on the little tree

Is making a different face at me!

Some look surprised when I pass by

And others droop-but they are shy

These two whose heads together press

Tell secrets I could never guess

Some have their heads thrown back to sign,

And all the buds are listening 
In the poetry, the poet describes a small rose garden in her garden as human characteristics and behavior. For example, the roses made different faces, it is said that some looked surprised as the writer passed by, while others ducked in embarrassment. It is depicted that there are two roses whose flowers are close to each other, as if telling a secret that has never been guessed. There are also some roses whose flowers sway back and forth as if they were singing, while the buds listened reverently.

Alpine Glow

by Emily Dickinson

Our lives are Swiss

In the sentence above, the poet describes human life as Swiss. Swiss are synonymous with cities that have the best quality of life.

From Alcuin

by Ralph Wando Emerson

The sea is the road of the bold

The word sea is not an object in the form of water. The word sea is identified with a human heart that must be brave in taking action.

A Man Young and Old: Human Dignity

by William Butler Yeats

Like the moon her kindness is

The sentence above describes the kindness of a person like the moon shines in the dark.

As though my sorrow were a scene Upon a painted wall

The sentence above describes the story of a person who is in sadness but he can cover up his sadness, so that other people do not know.

So like a bit of stone I lie

Under a broken tree

The sentence above describes someone who pretends to be strong and tough even though he is carrying a heavy burden.

Love and Friendship

by Emily Bronte

Love is like the wild rose-briar

Love is described as a rose-briar where each rose has beauty but also has thorns that can hurt us just like love has a dangerous and thrilling side.

Friendship like the holly-tree

In the sentence above, friendship is likened to a holly tree that remains green throughout the year and the poet of this poetry illustrates that this quality of consistency is also shared by true friendship. 
Mountain

by Ika

But your beauty is when the mist crawls Elegant..... Amazing....

The word your beauty which is usually used in humans is likened to the word mountain in this poem. When the fog slowly moves there the beauty of the mountain will appear clearly with a stunning charm.

My Star

by Robert Browning

Then it stops like a bird; like a flower, hang furled

In this poem the poet described his love as a star. So that, in the sentence "then it stops like a bird; like a flower, hang furled" the poet compares the sparkle of the star then stops like a birds soaring in the sky, like withered flowers. It can be interpreted that "star" in this poem did not shine anymore because the person he loves has gone far away from him.

They must solace themselves with the Saturn above it

In this verse the poet depicts Saturn as an entertainer where when the stars have left; they can entertain themselves with Saturn which has beauty.

I Wandered Lonely as a Cloud

by William Wordswoth

I wandered lonely as a Cloud

That floats on high o'er vales and hills

The sentence above describes someone who feels lonely in living his life even when in various difficulties he always feels alone.

Tossing their heads in sprightly dance

Tossing their heads does not mean turning head, but enjoying the music or dancing by shaking their heads to the spring dance.

The wave beside them danced, but they outdid the sparkling waves in glee

The sentence above explains that even though the problems that come are so heavy, if we go through them together it can be resolved properly.

\section{Discussion}

The results showed that there are types of metaphor according to Parera found in poetry in English textbook entitled "Pathway to English". From the poem entitled "The Seasons", "The Little Rose Tree", "Alpine Glow”, "From Alcuin", "A Man Young and Old: Human Dignity", "Love and Friendship", "Mountain", "My Star", and "I Wandered Lonely as a Cloud" consists of 22 lines that used metaphor.

In the first poetry entitled "The Seasons", there are 4 lines that included to anthropomorphic metaphor. In the second poetry entitled "The little Rose Tree", there are 2 lines that included to anthropomorphic metaphor and 3 lines that included to synesthetic metaphor. In the third poetry entitled "Alpine Glow", there is 1 line that included to anthropomorphic metaphor. In 
the fourth poetry entitled "From Alcuin", there is 1 line that included to anthropomorphic metaphor. In the fifth poetry entitled "A man Young and Old: Human Dignity", there are 2 lines that included to anthropomorphic metaphor and 1 line included to metaphor abstract to concrete. In the sixth poetry entitled "Love and Friendship", there are 2 lines that included to anthropomorphic metaphor. In the seventh poetry entitled "Mountain", there is 1 line that included to anthropomorphic metaphor. In the eighth poetry entitled "My Star", There is 1 line that included to animal metaphor and 1 line included to metaphor abstract to concrete. And in the last poetry entitled "I Wandered Lonely as a Cloud", there are 3 lines that included to anthropomorphic metaphor. The meaning of all these poetry is about life.

Based on the research that has been done, it is known that in the poetry in English textbook there are many sentences that used metaphor. However, in this research the researcher was limited to used the theory of Parera to analyze the types of metaphor in poetry so that only a few types of metaphors can be discussed. The researcher suggests that for future research to use a different theory with the same data so that all types of metaphors contained in poetry in English textbook entitled "Pathway to English" can be discussed totally.

The researcher also hopes that further researchers can carry out research on different data with different theory so that the readers know the different types of metaphor in a literary work such as poetry, song, novel and others. So that, the readers can understand the types of metaphors and the readers will no longer have difficulty to interpret the meaning of the poetry that used metaphor.

\section{CONCLUSION}

Based on the results the researcher concluded that the poetry in English textbook entitled "pathway to English" consists of 22 lines that used metaphor, which 16 lines are anthropomorphic metaphor, 3 lines are synesthetic metaphor, 2 lines are metaphor abstract to concrete and 1 line is animal metaphor. It can be said that the dominant types of metaphor is anthropomorphic metaphor. By using anthropomorphic metaphor the poet tries to describe their feeling or something by comparing the similarity of their experience or their own bodies.

From this analysis, the researcher concluded that metaphor is an important role in writing poetry. Through the use of metaphorical meaning the poetry becomes more interesting to read and also the poet help the readers imagine the poetry and by using metaphor the poet can also express their feelings to the reader to understand the implicit message contained in the poetry through the depiction or comparison made by the poet.

\section{ACKNOWLEDGMENTS}

First of all, The researscher would like to praise and thanks to God for his helping and blessing that has given, so the researcher can complete the research entitled Metaphorical Expression Used in Poetry in English Textbook Entitled "Pathway to English". Thanks to Mrs. Emma Martina Br. Pakpahan, S.Pd., M.A as the supervisor who has given much direction, suggestion, motivation, and also has spent her valuable time in guiding the researcher to accomplish this research article well. Thanks to my family and also my friends who have provided advice, prayers, and encouragement to the researcher. Thank to my idols X1 and SEVENTEEN who indirectly encourage the researcher through their song. So that, the researcher feel motivated and enthusiastic in completing the research. 


\section{REFERENCES}

Amriani, H. (2016). Metaphor and Simile in William Shakespeare's Poems (Metafora dan Simile dalam Puisi William Shakespeare). SAWERIGADING, 15(2), 169-177.

Nur Hasanah, D. (2018). An analysis of figurative language used in some poems by Oscar Wilde. Thesis. UIN Walisongo Semarang

Hutauruk, B. S. (2019). The Use of Figurative Languages on the Students' Poetry Semester V at FKIP Universitas HKBP Nommensen. Journal of English Language and Culture, 9(2).

Nurmayunita, D. (2017). Metaphor translation from an Indonesian poem entitled tidak ada New York hari ini into english. Thesis. UIN Syarif Hidayatullah Jakarta: Fakultas Adab Dan Humaniora.

Pambudi, R. T. (2016). Figurative Language Used in Robert Frost's Poems. Electronic Theses and Dissertations Universitas Muhammadiyah Surakarta.

Parera, J. D. (2004). Teori Semantik. Erlangga.

Pariasa, I. G., I. M. R. \& I. G. A. S. (2017). The Application of Metaphor Identification Procedure (MIP) and Conceptual Metaphor in Japanese Poetry. Linguistika, 24(1), 138157.

Group, P. (2007). MIP: A method for identifying metaphorically used words in discourse. Metaphor and Symbol, 22(1), 1-39.

Ade, P. (2017). An Analysis of Metaphor in Edgar Allan Poe's Poems. IAIN Syekh Nurjati Cirebon Repository.

Rahman, I. A. (2021). Metaphor Analysis on Students' English Poems. English Language in Focus (ELIF), 1(1), 1-8.

Steen, G. (2007). Finding Metaphor in Discourse: Pragglejaz and Beyond. Culture, Language and Representation, $V, 9-25$.

Syarwani, H. (2017). An Analysis of Metaphor in Emily Dickinson's Poems. Electronic Theses IAIN Ponorogo.

Telaumbanua, T. (2020). Metaphorical Expressions Used in Emily Dickinson's Poems. Jurnal Education and Development, 8(2), 555.

Theresia, S. \& E. G. (2017). Pathway To English untuk SMA/MA Kelas XI Kelompok Peminatan (Revisi). Jakarta: Erlangga.

Ulfa, T. M. (2016). The Metaphor Used in Anne Bradstreet's Poem. Electronic Theses Universitas Islam Negeri Maulana Malik Ibrahim Malang. 